\title{
The parameters of the acoustic insulation capacity of a reinforced wooden ceiling
}

\author{
Elżbieta Grochowska ${ }^{1, *}$, Joanna Kaliszuk ${ }^{1}$, and Jarosław Gil $^{2}$ \\ ${ }^{1}$ Faculty of Civil Engineering, Architecture and Environmental Engineering, University of Zielona \\ Góra, Zielona Góra, Poland. \\ ${ }^{2}$ Pomiaryakustyczne.net, Zielona Góra, Poland.
}

\begin{abstract}
The article presents the parameters of the acoustic insulation capacity of a traditional wooden ceiling before and after renovation in a historical building from the beginning of the 20th century. Due to a change in the use of the building, the existing wooden ceilings were reinforced with two symmetrical C-bars with the use of Cofrastra 40 composite steel-concrete slab. The composite slab, being the ceiling support, made it easy to mount a suspended ceiling with thermal and acoustic insulation layers specifically selected for the building's needs.
\end{abstract}

\section{Introduction}

Wooden ceilings in residential and public buildings were commonly used until the beginning of the 20th century. A wooden ceiling without any insulation layers can be called a „bare” ceiling. This kind of ceiling is characterized by poor acoustic insulation capacity. The obligation to provide acoustic protection to building users results from the provisions of the Building Code. According to the "Building Code", a building should not only meet the requirements regarding load-bearing capacity, structural stability or fire safety, but it should also protect against noise. During modernization of old buildings with wooden ceilings, construction partition should be properly designed to comply with legal requirements.

Sound can be a positive phenomenon, and under certain conditions, a negative one. Sounds that cause negative feelings are called ,noise" and affect people's health and wellbeing. „Noise” may refer to sounds produced by machines as well as sounds that are produced when the building is used by people.

The article describes and calculates the parameters of sound insulation capacity for four wooden ceiling options. This work concerns only the sound insulation capacity of the partition dividing flats (the ceiling), without the influence of lateral transmission. In order to fully assess the acoustic insulation between premises, it is necessary to consider not only the ceiling, but also the construction of the adjacent walls and joints between the partitions.

\footnotetext{
* Corresponding author: E.Grochowska@ib.uz.zgora.pl
} 


\section{Parameters defining the acoustic insulation capacity of a partition in a building}

Sound is a wave phenomenon caused by vibration of particles in any elastic medium. The sound transmitted through a building partition results from stimulating the partition to vibrate by an acoustic wave falling on it. Acoustic waves spread in the air or are stimulated mechanically. When an acoustic wave falls on a barrier, some of it is reflected, some is absorbed, and the rest penetrates to the other side. The acoustic insulation capacity of a partition is its ability to suppress the sound penetrating through it. The partition will have adequate acoustic insulation capacity when sounds coming from the other side will be incomprehensible and they will not disturb the users of the other rooms.

Depending on the way a partition is stimulated, two types of insulation are distinguished: insulation against airborne sounds and insulation against impact sounds. Impact sounds can be caused by walking on the other side of the ceiling or by moving or rolling objects.

\subsection{Parameters defining insulation capacity against airborne sounds}

The insulation capacity of a building partition against airborne sounds is referred to as the ability of the partition to reduce penetration by airborne sounds. Specific acoustic insulation capacity can be determined by the formula:

$$
R=L_{1}-L_{2}+10 \lg \frac{S}{A}
$$

where:

$L_{1}$ - the level of the average acoustic pressure in the room on the transmitting side [dB],

$L_{2}-$ the level of the average acoustic pressure in the room on the receiving side [dB],

$S-$ the area of the partition $\left[\mathrm{m}^{2}\right]$,

$A$ - acoustic absorption $\left[\mathrm{m}^{2}\right]$.

The standardized difference in sound pressure levels expressed by the formula (2) and the reference difference in sound pressure levels expressed by the formula (3) are used to determine the capacity of insulation between rooms in a building. The benchmark difference between the levels is the difference corrected for the reverberation time in the receiving room with respect to the time of $0,5 \mathrm{~s}$.

$$
\begin{aligned}
& D_{n}=L_{1}-L_{2}+10 \lg \frac{A}{A_{0}} \\
& D_{n T}=L_{1}-L_{2}+10 \lg \frac{T}{T_{0}}
\end{aligned}
$$

where:

$L_{1}, L_{2}, A-$ see above,

$A_{0}$ - reference acoustic absorption $\left(A_{0}=10 \mathrm{~m}^{2}\right)$,

$T$ - reverberation time [s],

$T_{0}-$ reference reverberation time $\left(T_{0}=0,5 \mathrm{~s}\right)$. 


\subsection{Parameters determining insulation capacity against impact sounds}

The insulation capacity of ceilings against impact sounds is determined by means of the impact level value that occurs in the room under the ceiling, when a standardized source of impact sounds is operating on the ceiling. The following impact levels are distinguished:

a) the standardized impact level $L_{\mathrm{n}}$, which is determined in laboratory conditions in the case of sound transfer to a room under the ceiling only for a particular floor structure:

$$
L_{n}=L_{i}+10 \lg \frac{A}{A_{0}}
$$

where:

$L_{i}$ - the level of average sound pressure in 1/3 octave bands in the receiving room, when a particular ceiling is stimulated by a standard sounder [dB],

$A, A_{0}$ - see above,

b) the approximate standardized impact level $L_{n}^{\prime}$, which is determined when the sound is transferred to the receiving room through the ceiling and through other channels sideways, e.g. through the walls:

$$
L_{n}^{\prime}=L_{i}+10 \lg \frac{A}{A_{0}}
$$

\section{Acoustic characteristics of wooden ceilings}

According to the law [6] “(...) external and internal partitions and their elements should have acoustic insulation at least on the level specified in the Polish Standard concerning the required acoustic insulation capacity of partitions in buildings and acoustic insulation capacity of building elements, determined according to the Polish Standards defining insulation measurement methods, acoustic construction elements and acoustic insulation in buildings (...)".

In order to obtain good acoustic insulation capacity against airborne and impact sounds, a ceiling should be characterized by good tightness, high surface mass and it should consist of at least two layers. It should also be properly connected with the other partitions and good workmanship should also be ensured. Moreover, the floor part has to be separated from the ceiling part. In addition, acoustic insulation capacity also strongly depends on the presence of mineral wool in the space between the beams. According to [3], suspended ceilings made of dry plasterboards on a structure made of cold-formed steel profiles have the most favourable characteristics.

From the acoustics point of view, wooden ceilings are two-component structures, usually with linear joints. The two-component structure consists of the floor and ceiling panels. These components are joined with basic supporting elements, i.e. wooden beams. Traditional wooden ceilings do not have sufficient insulation capacity against airborne sounds because of the small surface mass and rigid joints between the layers.

The standard [5] specifies the requirements for the sound insulation capacity of various building partitions. The standard should be used not only for the design and construction of buildings but also for the reconstruction of multi-family residential buildings, collective housing and public buildings. Meeting the standard conditions will ensure comfortable use of buildings. 
Depending on the structural design of a partition, the physical parameters of the material used may have a strong influence on its acoustic characteristics. Therefore, the acoustic properties of the material should always be considered for a particular structural solution.

\subsection{Structural and material design solution of a ceiling before and after modernization (reinforced ceiling)}

At present, there are traditional wooden ceilings in the building, which are described in detail in [2]. The cross-section of the existing wooden ceiling is shown in Fig. 1a. The ceiling consists of the following layers: PVC flooring, boards with a thickness of 28-32 $\mathrm{mm}$, filled with sawdust mixed with clay, ceiling beams with a cross-section of $21 \times 22 \mathrm{~cm}$, blind boards with a thickness of $20 \mathrm{~mm}$, ceiling boards with a thickness of $18 \mathrm{~mm}$, limestone plaster on reed with a thickness of $20 \mathrm{~mm}$.

a)

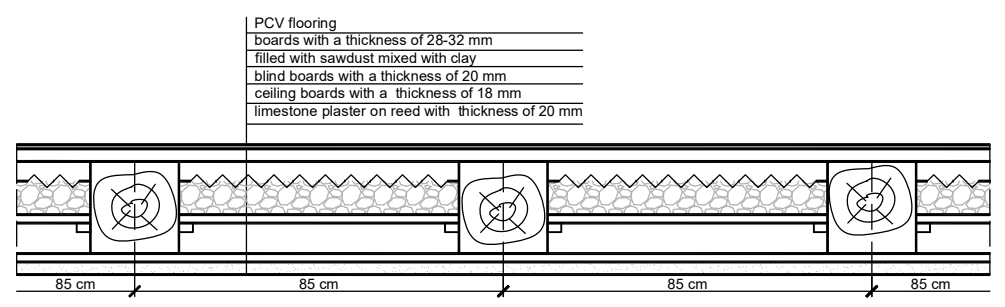

b)

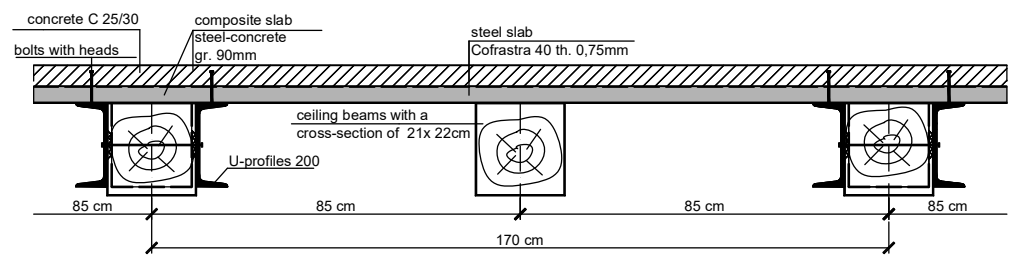

c)

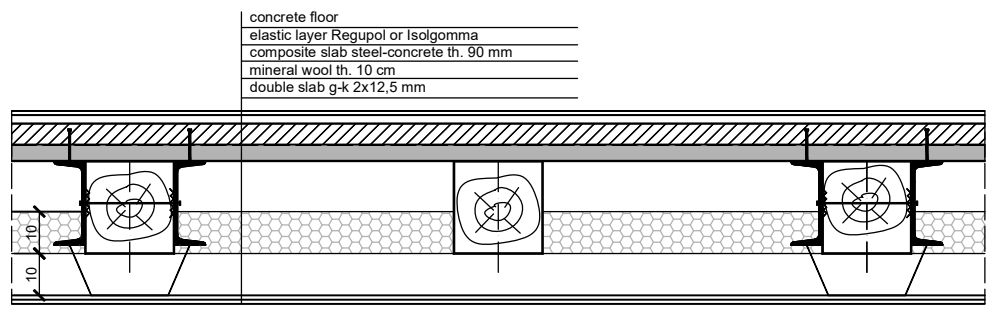

d)

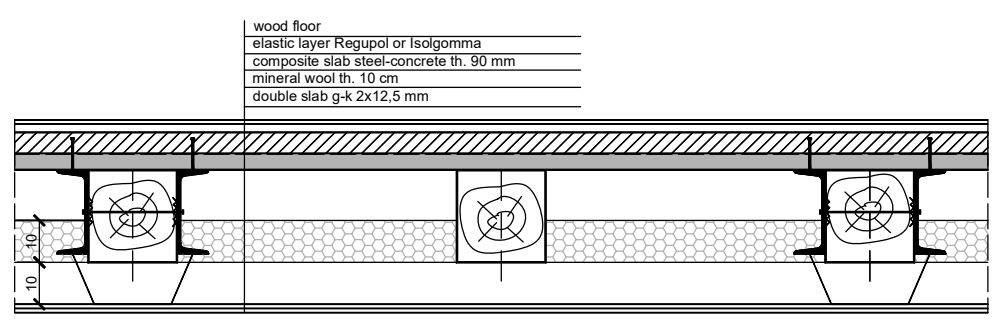

Fig. 1. Cross-sections of the wooden ceiling, a) the roof before renovation-option 1, b) the reinforced wooden ceiling without the floor surface and the suspended ceiling - option 2, c) the reinforced ceiling with the concrete floor surface and the suspended ceiling - option 3,d) the reinforced ceiling with the wooden floor surface and the suspended ceiling - option 4. 
When the use of the building changed, the load-bearing capacity of the existing ceiling became insufficient in terms of the applicable standards. The paper [1] presents a proposal to reinforce the wooden ceiling with two symmetrical U-profiles with the use of Cofrastra 40 composite steel slab. The cross-section of the reinforced ceiling, without the floor surface and suspended ceiling is shown in Fig. 1b. Fig. 1c shows the cross-section of a reinforced floor with a concrete floor on a Regupol or Isolgomma elastic layer with the use of a ceiling made of a double g-k (gypsum-cardboard) board, suspended $10 \mathrm{~cm}$ below the floor beams. Fig. 1d shows the cross-section of a reinforced floor with a wooden floor on a Regupol or Isolgomma elastic layer using a ceiling made of a double g-c (gypsumcardboard) board, suspended $10 \mathrm{~cm}$ below the floor beams.

According to the Building Code after the renovation of the building, the roof should meet the requirements not only regarding load-bearing capacity, serviceability and fire safety, but it should also protect the users against noise. The design solutions of floors and suspended ceilings that were applied will meet the standard requirements regarding the sound insulation capacity of ceilings depending on the purpose for which the building is used. It is assumed that the building may serve as a multi-family house and a public building.

\subsection{Determination of the sound insulation capacity of a wooden ceiling before and after renovation. Analysis of the results}

According to [4] the value of sound insulation capacity was reduced to single-number indicators. Due to the fact that the insulation capacity chart is different at low, medium and high frequencies, it was compared with the so-called standard curve according to [8]. Fig. 2 presents graphs with standard curves and calculated curves of sound insulation capacity against airborne and impact sounds for individual ceiling options (Fig. 1). The calculation procedure for determining a single-number indicator consists in determining an isolation graph and applying the standard curve to the graph. The reference curve moves in the direction of the insulation curve with an accuracy of $1 \mathrm{~dB}$, until the sum of the values on the other side of the standard curve (below for airborne sound insulation and above for shock sound insulation) will be about $32 \mathrm{~dB}$, but not more than $32 \mathrm{~dB}$. Then the weighted value is read for $500 \mathrm{~Hz}$.

Numerical simulations were carried out using the software Insul 8.0. This software calculates the material acoustic insulation capacity of partitions mainly on the basis of the calculation methods by Sharp [9] and Cremer [10]. The input data defined in the software Insul for calculating the specific acoustic insulation capacity $(\mathrm{R}, \mathrm{dB})$ are:

- thickness;

- density;

- Young's modulus;

- internal damping coefficient;

- type and thickness of the separation between the layers.

The surface mass and the limit frequency are calculated from the above input data. The software also has an internal database of ready-made construction elements with predefined physical parameters.

The parameters of material sound insulation capacity that were determined cannot be directly compared with the values required by the standard [5]. The occurrence of the lateral transmission phenomenon always makes the sound insulation capacity measured in completed premises a few $\mathrm{dB}$ lower than the laboratory values. If the side elements have low insulation capacity, this difference can even amount to several $\mathrm{dB}$. 

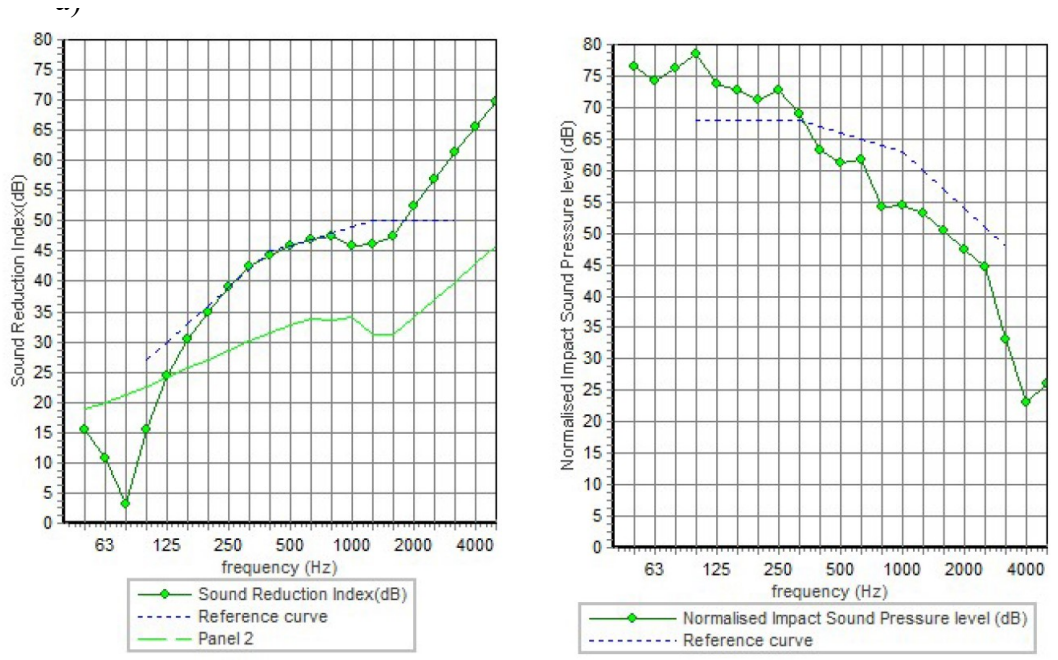

b)
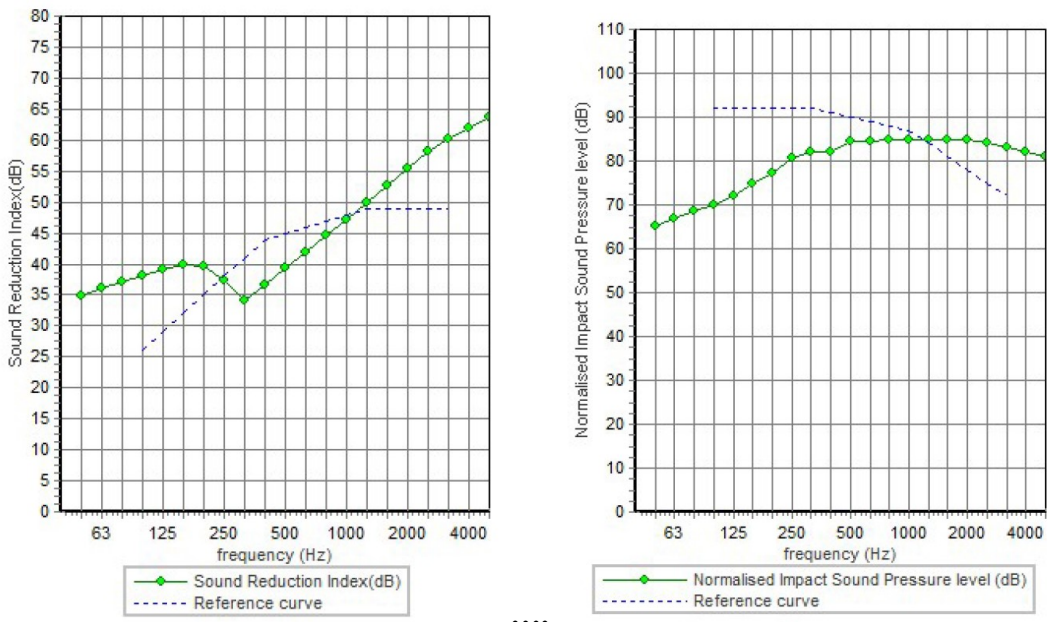

c)
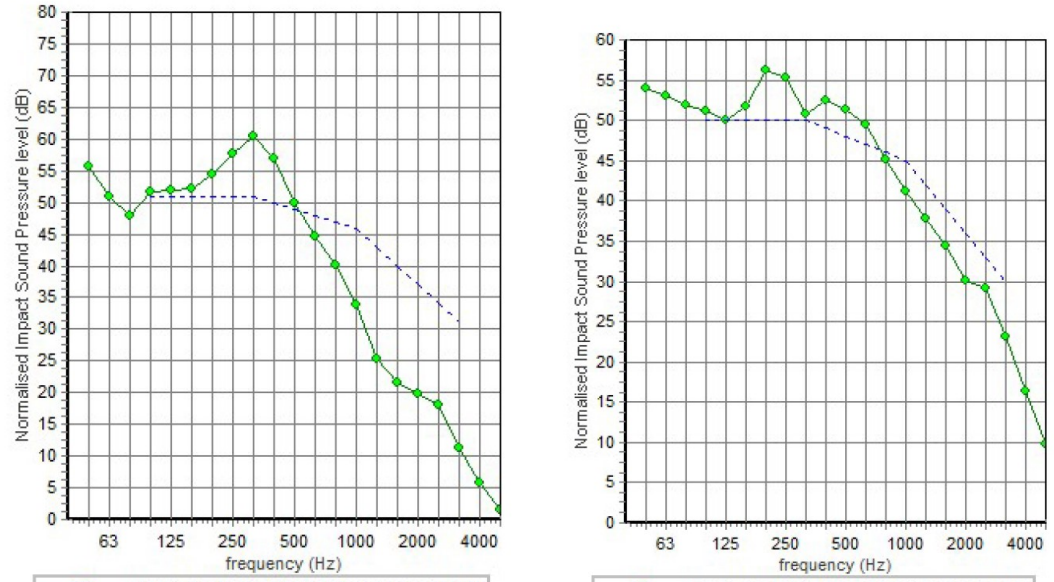

$\longrightarrow$ Normalised Impact Sound Pressure level (dB) $\longrightarrow$ Normalised Impact Sound Pressure level (dB) -......... Reference curve .... 
d)
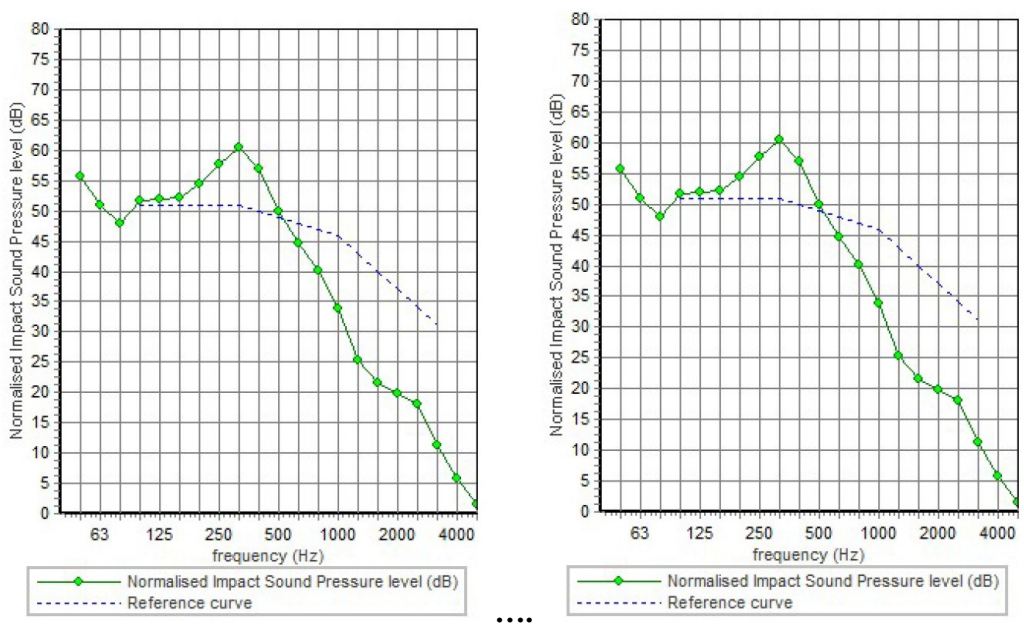

Fig. 2. Standard curves and calculated sound insulation capacity against airborne and impact sounds, a) option 1, b) option 2, c) option 3, d) option 4

For the purpose of this paper, it was assumed that the calculated sound insulation capacity values should be at least $6 \mathrm{~dB}$ better (higher in the case of $\mathrm{R}_{\mathrm{A}, 1}$ and lower in the case of $L_{n, w}$ ) than the values of $R_{A, 1}^{\prime}$ and $L_{n, w}^{\prime}$ presented in [5]. In order to more accurately determine the capacity of the sound insulation between the apartments, it would also be necessary to take into account the construction of the walls adjacent to the ceiling and the method of joining the partitions.

Table 1 presents the standard requirements for the acoustic insulation capacity of ceilings in multi-family and public buildings as well as the results of the calculations.

Table 1. The required and calculated sound insulation capacity of the ceiling in multi-family and public buildings according to [5].

\begin{tabular}{|c|c|c|c|c|}
\hline \multirow{3}{*}{$\begin{array}{c}\text { Ceiling } \\
\text { option } \\
\text { (see Fig. 1) }\end{array}$} & \multicolumn{2}{|c|}{ Standard requirements [5] } & \multicolumn{2}{|c|}{ Calculation results } \\
\hline & $\begin{array}{l}\text { Airborne } \\
\text { sounds }\end{array}$ & $\begin{array}{l}\text { Impact } \\
\text { sounds }\end{array}$ & Airborne sounds & Impact sounds \\
\hline & $\begin{array}{c}\mathrm{R}_{\mathrm{A} 1} \\
\min , \mathrm{dB}\end{array}$ & $\begin{array}{c}\mathrm{L}_{\mathrm{nw}}^{\prime} \\
\max , \mathrm{dB}\end{array}$ & $\mathrm{R}_{\mathrm{A}, 1}, \mathrm{~dB}$ & $\mathrm{~L}_{\mathrm{n}, \mathrm{w}}, \mathrm{dB}$ \\
\hline 1 & \multirow{4}{*}{51} & \multirow{4}{*}{55} & 42 & 66 \\
\hline 2 & & & 41 & 90 \\
\hline 3 & & & 61 & 49 \\
\hline 4 & & & 61 & 48 \\
\hline \multicolumn{5}{|c|}{$\begin{array}{l}\text { Legend: } \\
R_{A, 1}^{\prime} \text { - is a single-number indicator of approximate specific acoustic insulation capacity } \\
\text { against airborne sounds, the minimum value (applies to insulation capacity against } \\
\text { airborne sounds with a medium and high frequency spectrum in a situation where there } \\
\text { is lateral transmission through the surrounding building structure), } \\
L_{n, w}^{\prime} \text { - is a weighted single-number indicator of the level of standardized approximate } \\
\text { impact (taking into account the effect of lateral sound transmission). It describes the } \\
\text { reaction of the partition to impact sounds and vibrations. }\end{array}$} \\
\hline
\end{tabular}

The present traditional wooden ceiling (option 1) does not meet the requirements of the standard, as previously assumed.

The ceiling after reinforcement (option 2) with a composite steel-concrete slab, but without appropriate layers of floor and a suspended ceiling does not meet the requirements of the 
standard either. The tables [7] present the acoustic characteristics of the composite slab without the use of a suspended ceiling depending on the mass of the floor slab. For a ceiling thickness of $90 \mathrm{~mm}$, the acoustic insulation capacity $R_{w}\left(C ; C_{t r}\right)=45(0 ;-4) \mathrm{dB}$. The sound insulation capacity determined with the software Insual is comparable.

Ceilings made for options 3 and 4 with the use of concrete and wooden floors as well as suspended ceilings and mineral wool layers in the space between the floor and the ceiling will meet the standard requirements provided that the lateral transmission will be controlled by applying appropriate wall structures adjacent to the ceiling.

\section{Conclusions}

Renovation of buildings, especially historic ones, is sometimes a difficult task. The use of a building and its function may change over time. With changes in society, the purpose of historical buildings also changes, and more and more often they are used as cultural, office, commercial or educational facilities, not just residential ones, so renovations should allow for different functions.

Protection against noise, i.e. unwanted, annoying and harmful sound is now required by law, but unfortunately this requirement is often not observed. Buildings built in the past had to meet only the requirements concerning load capacity and stiffness, no attention was paid to acoustic or thermal insulation capacity.

The article describes the acoustic insulation capacity against airborne and impact sounds of the ceiling in a historic building from the beginning of the 20th century. It was determined using the computer software Insual. The analysis was carried out for the existing traditional wooden ceiling and for a ceiling reinforced with Cofrastra 40 composite steel slab. Appropriate design of the floor layers and suspended ceiling with an additional layer of mineral wool in the space between the floor slab and the ceiling makes it possible to increase the insulation capacity of the partition and meet the standard requirements. The calculations did not take into account lateral sound transmission, because the construction of the walls and joints between the partitions was not considered.

Properly solved building partitions will effectively protect building users against unwanted airborne and impact sounds.

\section{References}

1. E. Grochowska, J. Kaliszuk, Renowacje drewnianych stropów z wykorzystaniem zespolonych plyt stropowych (to be published)

2. A. Matysiak, E. Grochowska, K. Hamudi, Ekspertyza techniczna dotyczaca stanu technicznego budynku znajdującego się przy ul. dr Pieniężnego 27 w Zielonej Górze, Opracowanie Zespołu Rzeczoznawców przy PZITB oddział Zielona Góra, (Zielona Góra, 2014)

3. P. Klemm, Budownictwo ogólne. Fizyka budowli, praca zbiorowa tom 2, (Arkady, 2010)

4. J. Gil, Izolacyjność akustyczna w budownictwie mieszkaniowym, (Medium Grupa, Warszawa, 2015)

5. PN-B-02151-3:2015 - Akustyka budowlana. Ochrona przed hałasem w budynkach. Część 3: Wymagania dotyczące izolacyjności akustycznej przegród w budynkach elementów budowlanych 
6. Rozporządzenie Ministra Infrastruktury z dnia 12 kwietnia 2002 r. w sprawie warunków technicznych, jakim powinny odpowiadać budynki i ich usytuowanie (Dz.U. $2002 \mathrm{nr}$ 75, poz. 690)

7. Cofrastra 40. Tablice obciążen. ArcelorMittal, WWW.constructalia.com, 29.11.2017 r.

8. PN-EN ISO 717-1:2013-08 - Akustyka. Pomiar izolacyjności akustycznej w budynkach i izolacyjności akustycznej elementów budowlanych. Izolacyjność od dźwięków powietrznych

9. B. H. Sharp, Prediction Methods for the Sound Transmission of Building Elements. (Noise Control Engineering, 1978)

10. L Cremer, M. Heckl, B.A.T Petersson, Structural Vibrations and Sound Radiation and Audio Frequencies (Springer, 2005) 